\title{
Temporal distribution of Aedes aegypti Linnaeus (Diptera, Culicidae), in a Hospital in Cuiabá, State of Mato Grosso, Brazil
}

\author{
Danilo de Carvalho-Leandro ${ }^{1,3}$, Ana Lúcia Maria Ribeiro², Jorge Senatore Vargas Rodrigues², \\ Cleide Maria Riberiro de Albuquerque ${ }^{3}$, Anagela Maria Acel ${ }^{2}$, Fábio Alexandre Leal-Santos ${ }^{2}$, \\ Diniz Pereira Leite $\mathrm{Jr}^{2}$ \& Rosina Djunko Miyazaki²
}

${ }^{1}$ Centro de Pesquisas Aggeu Magalhães, Departamento de Entomologia. Avenida Professor Moraes Rego, s/n. Cidade Universitária, 50670-420 Recife-PE, Brasil. carvalho_bio@hotmail.com

${ }^{2}$ Laboratório de Entomologia Médica, Faculdade de Ciências Médicas, Universidade Federal de Mato Grosso, Av. Fernando Corrêa da Costa, S/N, 78060-900 Cuiabá-MT, Brasil. anadarlingi@yahoo.com.br; senatorevargas@yahoo.com.br; anagela.anjobio@gmail.com; alexandre3025@hotmail.com; djbiologico@gmail.com; miya@vsp.com.br

${ }^{3}$ Departamento de Zoologia, Universidade Federal de Pernambuco, - Av. Prof. Moraes Rego, S/N, Cidade Universitária, $50670-420$ Recife-PE, Brasil. cleide.ufpe@gmail.com

\begin{abstract}
Temporal distribution of Aedes aegypti Linnaeus (Diptera, Culicidae), in a Hospital in Cuiabá, State of Mato Grosso, Brazil. This study aimed at registering and monitoring the presence of Aedes aegypti in the University Hospital Júlio Muller, Cuiabá-MT, as well as investigating the influence of temperature and rainfall on its temporal distribution and egg densities in ovitraps. The study was performed from April/2007 to March/2008, utilizing ovitraps with $10 \%$ of hay infusion and a wood paddle as an oviposition substrate. For surveillance, one ovitrap was placed in each of the 12 points distributed throughout the hospital. Ovitraps were collected monthly at the end of a 5-day installation period. After egg counting, wood paddles were immersed in water to allow larval eclosion for species identification through optical microscopy. Egg Density Index (EDI), Positive Ovitraps Index (POI), and Mean Number of Eggs (MNE) were used for data analysis. The presence of $A$. aegypti in the hospital was registered throughout the study period, except in July. The MNE was proportionally higher in the internal area ( $\mathrm{n}=8.47 \mathrm{eggs} / \mathrm{paddle})$ when compared to the external area $(n=5.46$ eggs/paddle), and was higher in September/October 2007 and January/February 2008. A significant increase in EDI, POI and MNE was registered in periods where the average temperature was higher, and the increase in POI was also concomitant with an increase in rainfall. The continuous presence of $A$. aegypti in the hospital throughout the study period, points out the need of including this mosquito in the arthropod control list in this environment. This is particularly important, considering that $A$. aegypti is an important vector of several arboviroses.
\end{abstract}

KEYWORDS. Monitoring; ovitraps; rainfall; temperature.

RESUMO. Distribuição Temporal de Aedes aegypti Linnaeus (Diptera, Culicidae), em um Hospital de Cuiabá, Mato Grosso, Brasil. Esse estudo objetivou registrar e monitorar a presença de Aedes aegypti no Hospital Universitário Júlio Muller, Cuiabá - MT, bem como investigar a influência da temperatura e pluviosidade sobre sua distribuição temporal e densidade de ovos em ovitrampas. $\mathrm{O}$ estudo foi realizado de abril/2007 a março/2008, usando ovitrampas com 10\% de infusão de gramínea e uma palheta de madeira como substrato para oviposição. Para o monitoramento, uma ovitrampa foi colocada em cada um dos doze pontos distribuídos nas dependências do hospital. Mensalmente, as armadilhas eram recolhidas ao final do quinto dia de instalação. Após a contagem dos ovos, as palhetas foram imersas em água para eclosão das larvas e identificação da espécie alvo em microscopia óptica. Índice de Densidade de Ovos (IDO), Índice de Positividade de Ovitrampas (IPO) e Número Médio de Ovos (NMO) foram usados para análise dos dados. A presença do mosquito no hospital foi registrada ao longo de todo experimento, exceto em julho. A densidade média de ovos foi proporcionalmente maior na área interna ( $\mathrm{n}=8,47$ ovos/palheta) comparada à externa $(\mathrm{n}=5,46$ ovos/palheta). O NMO foi mais elevado nos meses de setembro e outubro de 2007, janeiro e fevereiro de 2008. Aumentos significativos do NMO, IPO e IDO, foram registrados com a elevação da temperatura, e no IPO com aumento da pluviosidade. A constante presença do mosquito A. aegypti no hospital, indica a necessidade de incluir esse mosquito na lista de controle de artrópodes nesse ambiente. Isso é particularmente importante, considerando que o A. aegypti é importante vetor de várias arboviroses.

PALAVRAS-CHAVE. Monitoramento; ovitrampas; pluviosidade; temperatura.

Factors such as large production of organic waste, accumulation of disposable material, proximity to residences and intense circulation of people, turn hospitals into favorable environments for the establishment of arthropods that may serve as an important vehicle of pathogens to humans (Bicho et al. 2007; Gazeta et al. 2007). Among the arthropods frequently found in hospitals are spiders, mites, bedbugs, mosquitoes, beetle larvae (Gazeta et al. 2007), cockroaches (Martinho 1998), flies (Daniel et al. 1992) and ants (Costa et al. 2006; Fowler et al. 1995; Tanaka et al. 2007). Although their role as disease vectors are, in most cases, unknown, part of the problems regarding hospital infections have been attributed to the mechanical dispersion of microorganisms through the legs of ants, including bacteria strains multiresistant to 
antimicrobials (Tanaka et al. 2007).

Besides its great epidemiological relevance, the presence of culicines that are potential disease vectors in hospitals have been neglected in arthropod monitoring activities in this environment. This is worrisome, especially in the case of dengue, whose vector in Brazil is the mosquito Aedes aegypti. In 2002, a modified vector control program based on experiences from previous programs, was implemented in Brazil and named the National Program of Dengue Control (Plano Nacional de Controle da Dengue - PNCD). This program standardized various dengue control actions throughout the country (BRASIL 2002). An important step include in the program was to include hospitals within the strategic points (SP) for monitoring A. aegypti. Hospitals may favor various modes of endogenous or exogenous dispersion of dengue, once people infected with dengue virus may serve as an infection source for non-infected mosquitoes. In addition, mosquitoes carrying the virus may infect healthy people or even immunodepressed patients that are being treated, increasing mortality risk or hospital occupancy due to the morbidity rate (Forattini 2002; Gazeta et al. 2007). Furthermore, mechanical transmission of bacteria through mosquito legs has been reported by Sramová et al. (1991).

In the capital of Mato Grosso, the A. aegypti control program is based on guidelines recommended by PNCD, with special attention to SPs, such as cemeteries, tyre stores, junkyards, scrap yards, or places with intense circulation of people, like schools, bus station and airports. However, little attention has been given to vector control in hospitals, a potentially critical environment. Health units usually receive people with suspicion of dengue. Among these units is the University Hospital Júlio Müller (UHJM), which is the only entirely public hospital in Cuiabá and receives only patients from the Unified Health System (Sistema Único de Saúde - SUS). People from all cities in the State of Mato Grosso and that may present all types of health issues go to UHJM for health assistance, thus this hospital is an area of intense human circulation.

The concomitant occurrence of people infected with dengue virus and patients with other health issues at the UHJM, led us to perform this study, which aimed at registering and monitoring the presence of $A$. aegypti, in different areas of the hospital. The temporal distribution of this mosquito and the influence of environmental variables (temperature and rainfall) on egg densities were also evaluated.

The study was carried out in University Hospital Júlio Müller (UHJM), located at $15^{\circ} 34^{\prime} \mathrm{S} 56^{\circ} 04^{\prime} \mathrm{O}$, in the city of Cuiabá, State of Mato Grosso, Brazil, and with an area of $3,178.33 \mathrm{~m}^{2}$. For trap installation, 36 grid cells were drawn on an aerial photograph (satellite) of UHJM, and twelve quadrants were randomly selected, corresponding to nine points in the external area and three points in the internal area. In the external area were: 1- Winter Garden I (watertank storage room); 2- Winter Garden II (hung on the wall); 3- Mango tree (back cabin); 4- Ambulance Area III (balcony); 5- Teaching Rooms (balcony); 6- Milk Supply (balcony); 7- Humans Resources (Balcony); 8- Blood Supply (balcony); 9- Main
Reception (balcony). In the internal area were: 10 - Obstetrics Triage (doctor's office); 11- Cleaning Room (bathroom); 12 - Centre for Image and Diagnostics (on top of the bathroom's sink). In parenthesis are the exact place where ovitraps were installed in each point. In the external area, natural (natural puddle in the garden and bromeliads) and artificial (wastebaskets uncapped accumulating rainwater, gutters and containers) potential breeding sites were identified. In the internal area, plant dishes with accumulated water, and drains and toilets into disuse were identified as potential artificial breeding sites. These sites were monitored and received no treatment during the study. The presence of mosquito larvae was not registered during this period.

The Oviposition traps (ovitraps), adapted from the Fay \& Perry model, described in 1965 , were utilized as a tool to monitor A. aegypti in the study area. The ovitraps consisted of black plastic recipients (made for plants), filled with 300 $\mathrm{ml}$ of 10\% hay infusion (Cynodon dactylon - Poaceae). This infusion was obtained through the fermentation of $42.2 \mathrm{~g}$ of dry hay that had been immersed in 5 liters of water for 7 days. Porous wood paddles $(2.0 \times 12.0 \mathrm{~cm})$ served as oviposition substrates in the traps. To allow hydration, paddles were immersed in clean water for two days before they were taken to the field. At the time traps were installed, paddles were properly identified with tags containing a designated identification number and the date of installation, and fixed to the traps by a metal device.

The traps installation was performed between April/2007 and March/2008. In each collection point, one ovitrap was installed monthly, in a spot protected from the sun and animals (external area) and from passing people (internal area), at a height that varied from 80 to $140 \mathrm{~cm}$ from the ground. Five days after installation, ovitraps were collected and, in order to maintain the conditions necessary for $100 \%$ embryo development, the wood paddles were immediately placed in a humid chamber (thermal container with wet towels underneath), where they were kept for $48 \mathrm{~h}$, and then transferred to a dry chamber (thermal container without wet towels) until they were totally dry. Paddles were further analyzed through a stereoscopic microscope (40x magnification), in order to verify the presence and number of eggs. After counting, all positive paddles were individually immersed in plastic containers ( $2 \mathrm{~L}$ plastic bottles cut at 15 $\mathrm{cm}$ from its base) with water, for larval eclosion.

All ecloded larvae were reared under laboratory conditions, fed on fish food and identified to species level. Identification of Aedes species was performed by observing $4^{\text {th }}$ instar larvae mounted in a microscope glass slide under an optical microscope. The morphological feature used for species identification was the eightieth abdominal segment, according to the Aedes classification key, described by Consoli \& Lourenço-de-Oliveira (1994).

The variation of mosquito distribution in the studied areas was analyzed through the Positive Ovitraps Index (POI: number of positive ovitraps/number of analyzed ovitraps $\mathrm{x}$ 100), while the difference among egg densities was evaluated through the Egg Density Index (EDI: egg number/positive 

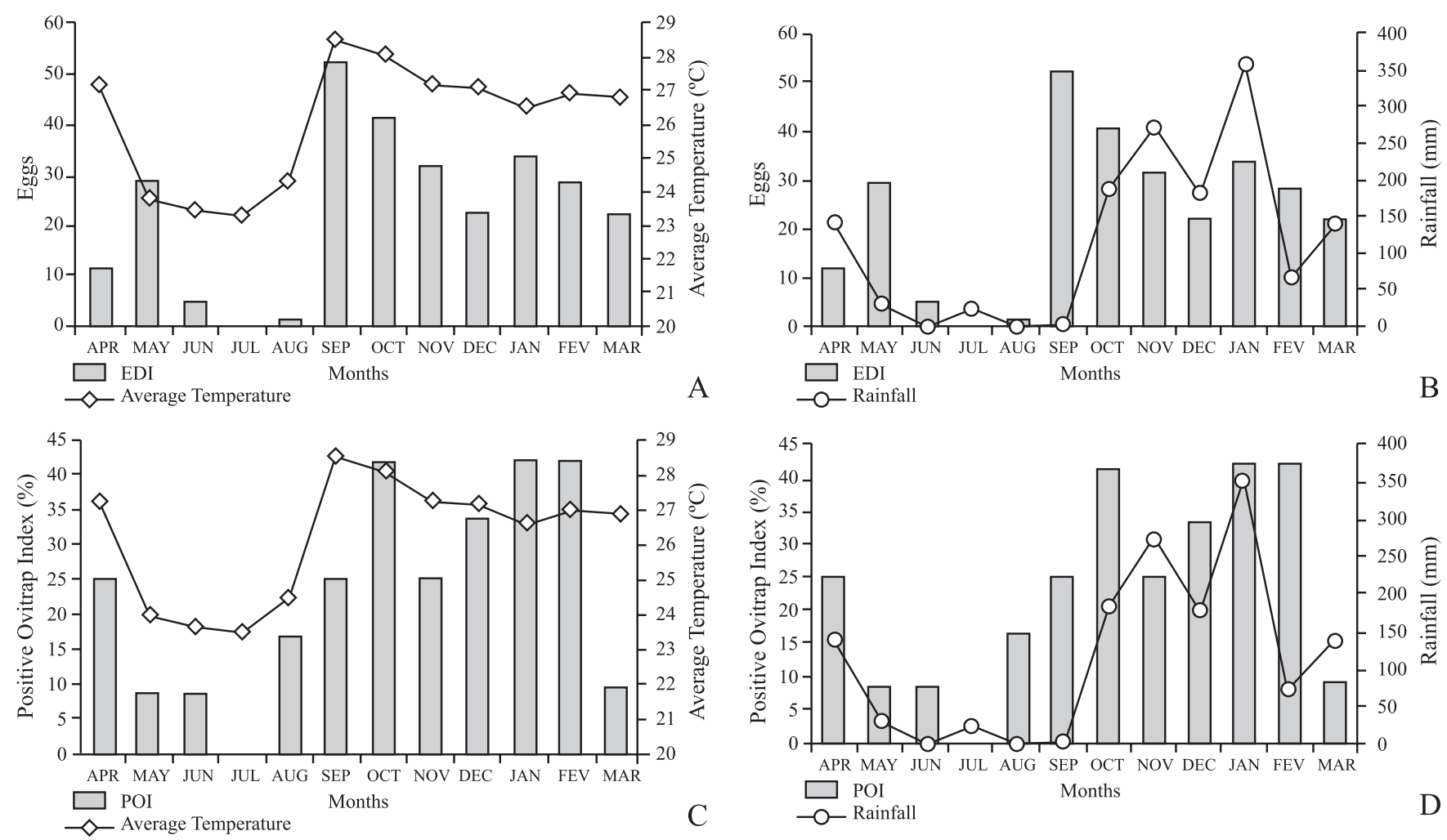

Fig. 1 Aedes aegypti egg densities and positive ovitraps related to environmental variables between April/2007 to March/2008 at the University Hospital Júlio Müller, Cuiabá-MT. Relationship between Egg Density Index (EDI) and average temperature (A) and rainfall (B). Positive Ovitrap Index (POI) in function of average temperature $(C)$ and rainfall (D).

ovitrap number) (Gomes 1998) and Mean Number of Eggs per ovitrap (MNE). Pearson correlation was utilized to compare the entomological indexes POI, EDI and MNE, and the environmental variables (mean temperature and rainfall), considering a $5 \%$ significant level.

All positive paddles $(\mathrm{n}=32)$ were immersed in plastic containers with water for larval eclosion. Out of 944 eggs collected, 797 hatched (hatching rate: $84 \%$ ), and 776 survived until $4^{\text {th }}$ instar $(82.2 \%)$. All surviving larvae were identified to species level, and all were A. aegypti.

Data obtained for POI, EDI and MNE are summarized on Table I. The presence of A. aegypti in the hospital, identified through POI, was registered throughout the study period, except in July. A variation in mosquito distribution among the study areas was observed, being Blood Supply, Cleaning Room, and Human Resources the areas with highest prevalence, and where the presence of eggs were registered in $50 \%, 41.6 \%$ and $41.6 \%$ of observations throughout the 12 month period, respectively. The Ambulance Area III (balcony) and Milk Supply (balcony) were the only ones where the presence of mosquito eggs was not observed (Table I). In the Teaching Room and Obstetrics Triage, the presence of $A$. aegypti was detected only in October/2007. During the 12month monitoring period, the points that presented the highest numbers of eggs were: Winter Garden II, Human Resources, Blood Supply and Cleaning Room, presenting, respectively, $11 \%, 15 \%, 12 \%$ and $24 \%$ of the total collected eggs.
During the study period, the mean egg density was proportionally higher in the internal area $(8.47$ eggs/wood paddle), when compared to the external area (5.46 eggs/ wood paddle). The mean egg number per paddle was higher in September (13 eggs/paddle) and October (17 eggs/paddle) 2007, and in January (13.91) and February (11.75) 2008. On the other hand, in June and August 2007, an average of less than 1 egg was found per ovitrap in a period of 5 days (Table I).

The MNE and ODI were strongly influenced by temperature. A significant increase in MNE $(\mathrm{p}<0.05)$ and ODI $(\mathrm{p}<0.05)$ was registered from September/2007 to March/2008, corresponding to the period where the mean temperature was the highest $\left(26.5^{\circ} \mathrm{C}-28.5^{\circ} \mathrm{C}\right)$. On the contrary, the lowest egg densities were observed on the months having the lowest mean temperature $\left(23.3^{\circ} \mathrm{C}-24.3^{\circ} \mathrm{C}\right)$, which were from May to August (Fig. 1-A).

Rainfall did not significantly affect egg densities ( $p>0.05$ ) during the study period, although in general the highest oviposition rates were observed during the rain period with rainfall of $68.9 \mathrm{~mm}-356.5 \mathrm{~mm}$ (Fig. 1-B).

A similar pattern of the effect of abiotic variables was obtained when the influence of temperature on ovitrap positive rate was evaluated. A significant higher number of ovitraps $(\mathrm{p}<0.05)$ containing at least one egg was registered during the periods of highest temperature (Fig. 1-C). The same occurred during the period of highest rainfall $(p<$ 
Table I. Entomological indicators of Aedes aegypti (MNE, EDI, POI) obtained through installation of ovitraps in the University Hospital Muller, between April/2007 to March/2008. In parenthesis are the exact place where ovitraps were installed in each point.

\begin{tabular}{|c|c|c|c|c|c|c|c|c|c|c|c|c|c|}
\hline No & Ovitrap localization & APR & MAY & JUN & JUL & AUG & SEP & OCT & NOV & DEC & JAN & FEB & MAR \\
\hline & External area & & & & & & & & & & & & \\
\hline 1 & Winter Garden I (watertank storage room) & 0 & 0 & 0 & 0 & 0 & 9 & 9 & 1 & 0 & 0 & 0 & 0 \\
\hline 2 & Winter Garden II (hung on the wall) & 0 & 0 & 0 & 0 & 0 & 0 & 0 & 0 & 0 & 32 & 71 & 0 \\
\hline 3 & Mango tree (back cabin) & 0 & 0 & 0 & 0 & 0 & 0 & 0 & 35 & 1 & 36 & 0 & 0 \\
\hline 4 & Ambulance Area III (balcony) & 0 & 0 & 0 & 0 & 0 & 0 & 0 & 0 & 0 & 0 & 0 & 0 \\
\hline 5 & Teaching Rooms (balcony) & 0 & 0 & 0 & 0 & 0 & 0 & 83 & 0 & 0 & 0 & 0 & 0 \\
\hline 6 & Milk Supply (balcony) & 0 & 0 & 0 & 0 & 0 & 0 & 0 & 0 & 0 & 0 & 0 & 0 \\
\hline 7 & Human Resources (balcony) & 1 & 0 & 0 & 0 & 1 & 0 & 39 & 0 & 68 & 0 & 34 & 0 \\
\hline 8 & Blood Supply (balcony) & 0 & 0 & 5 & 0 & 1 & 12 & 0 & 0 & 12 & 59 & 0 & 22 \\
\hline 9 & $\begin{array}{l}\text { Main Reception (balcony) } \\
\text { Internal area }\end{array}$ & 29 & 0 & 0 & 0 & 0 & 0 & 0 & 0 & 8 & 4 & 28 & 0 \\
\hline 10 & Obstetrics Triage (doctor's office) & 0 & 0 & 0 & 0 & 0 & 0 & 36 & 0 & 0 & 0 & 0 & - \\
\hline 11 & Cleaning Room (bathroom) & 4 & 29 & 0 & 0 & 0 & 135 & 0 & 59 & 0 & 0 & 6 & 0 \\
\hline 12 & $\begin{array}{l}\text { Centre of Image and Diagnostics } \\
\text { (on top of the bathroom's sink) }\end{array}$ & 0 & 0 & 0 & 0 & 0 & 0 & 37 & 0 & 0 & 36 & 2 & 0 \\
\hline & EDI1 & 11.3 & 29.0 & 5.0 & 0 & 1.0 & 52.0 & 40.8 & 31.6 & 22.2 & 33.4 & 28.2 & 22.0 \\
\hline & POI2 & 25.0 & 8.3 & 8.3 & 0 & 16.6 & 25.0 & 41.6 & 25.0 & 33.3 & 41.6 & 41.6 & 9.0 \\
\hline & MNE3 & 2.8 & 2.4 & 0.4 & 0 & 0.1 & 13.0 & 17.0 & 7.9 & 7.4 & 13.9 & 11.7 & 1.8 \\
\hline & Total Number of Eggs & 34 & 29 & 5.0 & 0 & 2.0 & 156.0 & 204 & 95.0 & 89.0 & 167.0 & 141.0 & 22.0 \\
\hline
\end{tabular}

1- EDI: Egg Density Index;

2- POI: Positive Ovitrap Index;

3- MNE: Mean Number of Eggs. (-) : Lost ovitrap

0.05), where increased POI was observed on October/2007 and January $/ 2008$, which presented $188.2 \mathrm{~mm}$ e $356.5 \mathrm{~mm}$ of rainfall, respectively (Fig. 1-D).

Over the past three years, the number of dengue cases has increased considerably in Cuiabá. According to data obtained from SINAN/2010 (Sistema de Informação de Agravo de Notificação), there were 977 dengue cases in 2007, 952 cases in 2008 and 12556 cases in 2009. The National Program of Dengue Control in Brazil emphasizes the relevance of entomological surveillance and vector control activities in various environments, such as strategic points. In this context, hospitals can be considered as special environments, due to their complex environment and importance regarding dengue transmission.

Besides the epidemiological importance of culicines as vectors of various pathogens of medical importance, studies on the presence of these insects in hospitals are scarce, and the majority of such studies have emphasized arthropods in general. Reports on the distribution of $A$. aegypti in hospitals in Brazil were not found in our literature review. Thus, this study represents the first record of $A$. aegypti and its distribution in a Brazilian hospital. In the UHJM, positive places for $A$. aegypti were registered in Winter Garden I, Winter Garden II, Mango tree, Teaching Rooms, Human Resources, Blood Supply, Main Reception, Obstetrics Triage, Cleaning Room, Centre of Image and Diagnostics. In a similar study performed by Daniel et al. (1992) in Prague, mosquitoes were found in the infirmary, reception, laboratory and kitchen areas. They also observed high infestation levels of other arthropods in spaces where services related to dermatology, urology and infectious diseases were performed. Other arthropods besides mosquitoes were not analyzed in our work. Still in Prague, Sramová et al. (1991), recorded 6\% of mosquitoes in a total of 161 arthropods collected in a hospital from July to September 1990. In the State of Rio de Janeiro, Brazil, Gazeta and colleagues performed a study in 2007 on the arthropods present in two health units. They found Zoraptera and Hymenoptera adults, Coleoptera larvae and adults, and Hemiptera and Diptera specimens. Among the Diptera found, there were members of Drosophilidae, Sarcophagidae and Culicidae families. The species Culex quinquefasciatus, belonging to the Culicidae family, comprised $5 \%$ of the total arthropods, being present in the hospital's reception, infirmary, laboratory and kitchen.

The higher Positive Ovitrap Index in the hospital interior area, compared to the external area is in disagreement to other studies in the literature on the oviposition behavior of $A$. aegypti. Dibo et al. 2005, in the city of Mirassol, State of São Paulo, aiming to determine $A$. aegypti preferred sites inside and outside residences have installed traps in the bedroom and living room (internal area), balcony or service area (external area - sheltered site), and under tree branches (external area - exposed to weather). The authors found a significant higher positivity rate in traps placed in the external area (52.9\% balcony or service area; $64.0 \%$ - under leaves tree branches), compared to the internal area (23.7\% - bedroom; 24.7 - living room). Yet in a study performed in Mexico, Lenhart et al. (2005) recorded similar results, where a higher positivity rate for $A$. aegypti eggs was found in ovitraps localized outdoor $(6.0 \%)$, compared to indoor $(4.5 \%)$. The higher positivity in the internal area found in our study may possibly be explained by the intense circulation of people in this environment, and by the presence of sheltered sites for $A$. aegypti such as winter garden I and II.

Factors such as temperature and rainfall are mentioned by various authors as critical for the establishment of mosquito 
populations in diverse environments (Glasser \& Gomes 2002; Gomes et al. 2006; Keating 2001; Ribeiro et al. 2006; Stein et $a l$. 2005). These factors may influence survival, reproduction and changes in the distribution and density of vectors (Keating 2001), resulting in a positive relation to dengue transmission dynamics (Forattini 2002). Although Ae. aegypti was found in all seasons at UHJM, the higher egg density and positive ovitrap percentage in months where the average temperature was higher, reinforce the influence of this factor on mosquito population dynamics, as described in other works. In Chaco (Argentine), an increase in wild Ae. aegypti populations was associated to periods of higher temperature and rainfall (Stein et al. 2005).

It is important to observe that egg density in the ovitraps installed in UHJM was low if the mean oviposition average of Ae. aegypti females is considered $(\mathrm{n}=50-150$ eggs/ oviposition) (Consoli \& Lourenço-de-Oliveira 1994). The "skip oviposition" behavior of this species (Chadee 2004) may have affected this result and may indicate the presence of other breeding sites in the hospital.

Rainfall was a determinant in ovitrap colonization by $A e$. aegypti females, even in the ones placed internally. An increase in rainfall results in an increase in breeding sites, which may result in mosquito population growth. The higher egg densities observed in the rain season is probably a reflection of the presence of more insects in the environment during this period, resulting in a more intense search for oviposition sites and thus in a higher POI and EDI. Quiescent eggs may have contributed to a higher population density, once they can be activated in the presence of water. Field studies performed in Recife (Regis et al. 2008) show a rapid increase in vector density after rainy periods, with larvae ecloding from eggs that had been accumulated in the walls of breeding sites during the dry season. The increase in Ae. aegypti population associated to climatic changes, particularly to higher temperature and rainfall, have been described in various works (Glasser \& Gomes 2002; Gómez et al. 2001; Regis et al. 2008; Ribeiro et al. 2006; Serpa et al. 2006; Stein et al. 2005; Vezzani et al. 2004). The contradictory data obtained in September, when the highest oviposition and lowest rainfall were observed, may possibly reflect a reduction in the number of available breeding sites in the external area (i.e. no accumulation of water in potential breeding sites), favoring the search for ovitraps located in the internal area.

Although Ae. aegypti presents great dispersion capability (Harrington et al. 2005; Honório et al. 2003), the absence of eggs in ovitraps located in the Milk Supply (balcony) and Ambulance Area III (balcony), places with a reduced circulation of people, suggest that females may remain in areas that provide easy feeding and oviposition sites.

To conclude, the constant presence of $A$. aegypti in UHJM observed here, reinforces the need for effective actions to control this insect in hospitals, with the aim of reducing the vector population, as already recommended by the National Program of Dengue Control. Our study indicates that, even when following all the rules of the national plan, as it is the case of the hospital in Cuiabá, novel vector control actions should be implemented in hospitals once they may be an important place for dengue dissemination. Additionally, the presence of infected mosquitoes in these environments could augment lethality risk in immunodepressed patients being treated in the hospitals.

\section{REFERENCES}

Bicho, C. L.; M. L. C. Brandão \& S. M. Pires. 2007. Mirmecofauna (Hymenoptera, Formicidae) em hospitais e postos de saúde no município de Bagé, RS. Arquivos do Instituto Biológico 74: 373-377.

Brasil. Ministério da Saúde, Fundação Nacional de Saúde. 2002. Programa Nacional de Controle da Dengue, Brasília, Ministério da Saúde, 28 p.

Chadee, D. D. 2004. Observations on the seasonal prevalence and vertical distribution patterns of oviposition by Aedes aegypti (L.) (Diptera: Culicidae) in urban higth-rise apartments in Trindad, West Indies. Journal Vector Ecology 29: 323-330.

Consoli, R. A. G. B. \& R. Lourenço-de-Oliveira. 1994. Principais mosquitos de importância sanitária no Brasil. Rio de Janeiro, Ed. Fiocruz, 228 p.

Costa, S. B.; A. Pelli; G. P. Carvalho; A. G. Oliveira; P. R. Silva; M. M. Teixeira; E. Martins; A. P. S. Terra; E. M. Resende; C. C. H. B. Oliveira \& C. A. Morais. 2006. Formigas como vetores mecânicos de microorganismos no Hospital Escola da Universidade Federal do Triângulo Mineiro. Revista da Sociedade Brasileira de Medicina Tropical 39: $527-529$.

Daniel, M.; H. Sramová; V. Absolonava; D. Dedicová; H. Ihotavá; L. Masková \& P. Petrás. 1992. Arthropods in a hospital and their potential significance in the epidemiology of hospital infections. Folia Parasitologica 39: 159-170.

Dibo, M. R.; F. Chiaravalloti-Neto; M. Battigaglia; A. Mondini; E. A. Favaro; A. A. C. Barbosa \& C. M. Glasser. 2005. Identification of the best ovitrap installation sites for gravid Aedes (Stegomyia) aegypti in residences in Mirassol, state of São Paulo, Brazil. Memórias do Instituto Oswaldo Cruz 100: 339-343.

Fay, R. W. \& A. Perry. 1965. Laboratory studies of ovipositional preferences of Aedes aegypti. Mosquito News 25: 276-281.

Forattini, O. P. 2002. Culicidologia médica: identificação, biologia e epidemiologia. São Paulo, Edusp, 864 p.

Fowler, H. G.; O. C. Bueno \& F. F. Anaraurana. 1995. Spatial Organization of the Ant Fauna (Hymenoptera: Formicidae) of a Small Private Hospital in Southern Brasil. Naturalia 20: 83-88.

Gazeta, G. S.; M. L. Freire; O. S. Ezequiel; A. J. M. Nunes; S. V. Ferreira \& A. N. Norberg. 2007. Artrópodes capturados em ambiente hospitalar do Rio de Janeiro, Brasil. Revista de Patologia Tropical 36: 254-264.

Glasser, C. M. \& A. C. Gomes. 2002. Clima e sobreposição da distribuição de Aedes aegypti e Aedes albopictus na infestação do Estado de São Paulo. Revista de Saúde Publica 36: 166-172.

Gomes, A. C. 1998. Medidas dos níveis de infestação urbana por Aedes (Stegomyia) aegypti e Aedes (Stegomyia) albopictus em programas de Vigilância Entomológica. Informe Epidemiológico do SUS 7: 49-57.

Gomes, A. S.; C. J. S. Sciavico \& A. E. Eiras. 2006. Periodicidade de oviposição de fêmeas de Aedes aegypti (Linnaeus, 1762) (Diptera: Culicidae) em laboratório e campo. Revista da Sociedade Brasileira de Medicina Tropical 39: 327-332.

Gómez, F. E.; C. M. H. Suárez \& R. C. Cárdenas. 2001. Factores que modifican los índices larvarios de Aedes aegypti en Colima, México. Revista Panamericana de Salud Publica 10: 6-12.

Harrington, L. C.; T. W. Scott; K. Lerdthusnee; R. C. Coleman; A. Costero; G. G. Clark; J. J. Jones; S. Kitthawee; P. Kittayapong; R. Sithiprasasna \& J. D. Sithiprasasna. 2005. Dispersal of the dengue vector Aedes aegypti within and between rural communities. American Journal Tropical Medicine and Hygiene 72: 209-220.

Honório, N. A.; W. C. Silva; P. J. Leite; J. M. Gonçalves; L. P. Lounibos \& R. Lourenço-de-Oliveira. 2003. Dispersal of Aedes aegypti and Aedes albopictus (Diptera: Culicidae) in an urban endemic dengue area in the State of Rio de Janeiro, Brazil. Memórias do Instituto Oswaldo Cruz 98: 191-198.

Keating, J. 2001. An investigation into the cyclical incidence of dengue 
fever. Social Science \& Medicine 53:1587-1597.

Lenhart, A. E.; M. Walle; H. Cedillo \& A. Kroeger. 2005. Building a better ovitrap for detecting Aedes aegypti oviposition. Acta Tropica 96: $56-59$.

Martinho, G. H. 1998. Limpeza Hospitalar, p. 87-92. In: A. C. Oliveira, C. P. Albuquerque, L. C. M. Rocha (orgs). Infecções hospitalares. Abordagem, prevenção e controle. Rio de Janeiro, Ed. Medsi, 466 p.

Regis, L.; A. M. Monteiro; M. A. V. Melo-Santos; J. C. Silveira Jr; A. F. Furtado; R. V. Acioli, G. M. Santos; M. Nakazawa; M. S. Carvalho, P. J. Ribeiro Jr \& W. Souza. 2008. Developing new approaches for detecting and preventing Aedes aegypti population outbreaks: basis for surveillance, alert and control system. Memórias do Instituto Oswaldo Cruz 103: 50-49.

Ribeiro, A. F.; G. R. A. M. Marques; J. C. Voltolini \& M. L. F. Condino. 2006. Associação entre incidência de dengue e variáveis climáticas. Revista de Saúde Publica 40: 671-676.
Serpa, L. L. N.; K. V. R. M. Costa; J. C. Voltolini \& I. Kakitani. 2006. Variação sazonal de Aedes aegypti e Aedes albopictus no município de Potim, São Paulo. Revista de Saúde Publica 40: 01-05.

Sramová, H.; M. Daniel; V. Absolonová; D. Dedizová; Z. Jedlicková; H. Lhotavá; P. Petrás \& V. Subertová. 1991. Epidemiological role of arthropods detectable in health facilities. Journal Hospital Infection. 20: $281-292$.

Stein, M.; G. I. Oria; W. R. Almirón \& J. A. Willener. 2005. Flutuación estacional de Aedes aegypti en Chaco, Argentina. Revista de Saúde Publica 39: 559-564.

Tanaka, I. I.; A. M. F. S. Viggiani \& O. C. Person. 2007. Bactérias veiculadas por formigas em ambiente hospitalar. Arquivos Médicos do ABC 32: $60-63$.

Vezzani, D.; S. M. Velázquez \& N. Schweigmann. 2004. Seasonal Pattern of Abundance Aedes aegypti (Diptera: Culicidae) in Buenos Aires City, Argentina. Memórias do Instituto Oswaldo Cruz 99: 351-356. 